\title{
The Effect of the Process-Based Approach on the Writing Skills of Bilingual Elementary Students
}

El efecto del enfoque basado en procesos sobre la escritura de estudiantes de primaria bilingüe

O efeito da abordagem baseada em processos na escrita de alunos bilíngues do ensino fundamental

Luisa Fernanda SÁNCHEZ VEGA Asociación Colegio Granadino, Caldas, Colombia.

lsanchez@granadino.edu.co https://orcid.org/000o-0002-6247-6050.

Margarita María LÓPEZ PINZÓN

Universidad de Caldas, Colombia. margarita.lopez@ucladas.edu.co https://orcid.org/oooo-0002-6755-3764.

Received: 05/02/2019

Sent to peer review: 04/03/2019

Accepted by peers: 09/04/2019

Approved: 23/04/2019

DOI: 10.5294/laclil.2019.12.1.4

To reference this article (APA) / Para citar este artículo (APA) / Para citar este artigo (APA) Sánchez, L. F., \& López, M. M. (2019). Analysing mathematical word problem solving with secondary education CLIL students: A pilot study. Latin American Journal Of Content \& Language Integrated Learning, 12(1), 72-98. DOI: https://doi.org/10.5294/laclil.2019.12.1.4 
ABSTRACT. The objective of this action research study was to assess the impact of the Process-Based Approach (PBA) on the development of the writing skills of young students who are learning English as a Foreign Language. The participants included 12 third-grade students from a bilingual private school in Manizales, Caldas. Six workshops were implemented, guiding the students to write different texts in English by using the writing process stages and applying some writing strategies, such as planning, monitoring, and evaluating their own output. Instruments such as a teacher's journal, a writing rubric, external observations, self-assessment protocols, and L2 writing pre- and post-tests were used to collect the data. The results suggest that the PBA was useful for enhancing the writing skills of young English learners. Additionally, the strategies applied during the process bettered third-grade students' writing performance in aspects such as content, organization, conventions, vocabulary, and fluency. Finally, the data illustrated that the PBA and the writing strategies made students feel confident about writing, which, at the same time, contributed to the students' self-efficacy in writing tasks.

Keywords (Source: Unesco Thesaurus): ESL writing for youngsters; English as a second language; process approach to writing; writing strategies; bilingual education; second language instruction; writing.

RESUMEN. El propósito de este estudio de investigación-acción fue evaluar el impacto del enfoque basado en procesos en el desarrollo de la habilidad de escritura de estudiantes de inglés como segunda lengua. Los participantes fueron 12 estudiantes de grado tercero de primaria pertenecientes a un establecimiento privado y bilingüe en Manizales, Caldas. Se implementaron seis talleres en los que se orientó a los estudiantes para escribir diferentes textos en inglés a través de las etapas del proceso de escritura y mediante la implementación de algunas estrategias de escritura como la planificación, el monitoreo y la evaluación en la producción de sus textos. Los instrumentos empleados para recolectar datos fueron un diario de campo, la producción escrita de los estudiantes, rúbricas, formatos de evaluación externa, autoevaluaciones de estudiantes y una evaluación previa y después de la intervención. Los resultados sugieren que el enfoque basado en procesos fue una intervención útil para mejorar la escritura de los estudiantes de tercer grado. Adicionalmente, las estrategias empleadas durante el proceso mejoraron el desempeño en escritura de los estudiantes en aspectos como contenido, organización, recursos grafológicos, vocabulario y fluidez. Finalmente, los resultados mostraron que el enfoque basado en procesos y las estrategias de escritura generaron confianza en los estudiantes hacia la escritura y al mismo tiempo contribuyeron a la autoeficacia para escribir.

Palabras clave: escritura en inglés como segunda lengua para niños; inglés como segunda lengua; enfoque basado en procesos para la escritura; estrategias de escritura; educación bilingüe; enseñanza primaria; enseñanza de una lengua extranjera; escritura.

RESUMO. O objetivo deste estudo de pesquisa-ação foi avaliar o impacto da abordagem baseada em processos no desenvolvimento da capacidade de escrita de estudantes de inglês como segunda língua. Os participantes foram 12 alunos do terceiro ano do ensino fundamental pertencentes a um estabelecimento particular e bilíngue em Manizales, Caldas. Foram realizadas seis oficinas, nas quais os alunos foram orientados a escrever diferentes textos em inglês através das etapas do processo de escrita e da implementação de algumas estratégias de escrita, como o planejamento, o monitoramento e a avaliação na produção de seus textos. Os instrumentos utilizados para a coleta de dados foram um diário de campo, a produção escrita dos estudantes, rubricas, formatos de avaliação externa, auto avaliações dos alunos e uma avaliação pré e pós-intervenção. Os resultados sugerem que a abordagem baseada em processos foi uma intervenção útil para melhorar a escrita dos alunos da terceira série. Além disso, as estratégias utilizadas durante o processo melhoraram o desempenho da escrita dos estudantes em aspectos como conteúdo, organização, recursos grafológicos, vocabulário e fluência. Finalmente, os resultados mostraram que a abordagem baseada em processos e as estratégias de escrita geraram confiança nos estudantes em relação à escrita e, ao mesmo tempo, contribuíram para a auto eficácia na escrita.

Palavras-chave: escrita em inglês como segunda língua para crianças; abordagem baseada em processos para a escrita; estratégias de escrita; educação bilíngue; educação primária; ensino de uma língua estrangeira; escrita. 


\section{Introduction}

Teaching young learners demands a high level of commitment. It is advisable for teachers to use resources that innovate and enhance the learner's communicative competence in a student-centered classroom. Moreover, they should have accountable knowledge about the children's characteristics and growth process to meet their needs when learning a foreign language.

As regards the development of the four skills of language, Fountas and Pinnell (2011) claim that there are essential elements in the foundational literacy skills, which include writing as one of the most important aspects to be developed. When young learners are in the process of acquiring the habit of writing, teachers may find two aspects that can be seen as drawbacks. First, they find writing difficult due to a lack of vocabulary knowledge, as well as spelling, syntax and grammar errors in their written pieces. Second, there is no interest in addressing writing activities. Therefore, this research project aimed at examining the effect of the process-based approach (PBA) suggested by Harmer (2004) and some writing strategies proposed by Serravallo (2017) and Oxford (2001) to plan, monitor, and evaluate elementary students' writing skill at a private bilingual school.

The researchers expected to learn about the impact of the PBA in the improvement of writing skills. Thus, a set of workshops were designed to assess the students' difficulties in writing, to generate positive perceptions about their writing process in English and to help the students improve their writing features.

A qualitative research method was followed under the action research principles, which involved a cyclical process including the stages proposed by Kemmis and McTaggart (1988): planning, acting, observing, and reflecting. Thus, it was carried out in three stages: diagnosis, action, and evaluation, in which the implementation of different instruments was essential to collect and analyze the data to report the results and the sample population, including 12 third-grade students.

After administering several instruments in the diagnostic stage, it was found that students were unfamiliar with linguistic features and the use of writing traits: sentence fluency, vocabulary, word choice, 
and conventions. Students showed difficulties producing fluent and coherent texts. These linguistic, lexical, syntactic and procedural errors are related to children' developmental stage when they acquire the second language. Gass and Selinker (2008) argue that, if young learners need to learn a complex set of abstractions, such as grammar, spelling patterns, and sentences structure, there must be something other than the language input to which they are exposed that helps them to learn language with relative ease and speed.

The general objective of this research project was to assess the impact of the PBA on the English as a foreign language (EFL) students' writing production. The researchers expected that, by taking part in EFL lessons and using strategic tools to generate ideas, draft, revise, and edit, the students could improve their written production in English. Moreover, the participants were expected to consider scaffolding when writing in the L2 after completing the pedagogical intervention.

During the action stage, six workshops were implemented to improve the writing skills of the students through a process-based intervention. To determine the impact, different instruments were administered, which provided valuable data about the students' perceptions of their process and their progress. The analysis of the results showed that there was a significant improvement on the students' ability to write. Learners enhanced their fluency and the length of their sentences; their vocabulary range also increased, and their spelling, punctuation and capitalization improved. It was confirmed that the PBA implemented in this study produced a positive effect on the students' writing ability and self-efficacy, as well as positive attitudes towards writing.

\section{Literature Review}

\section{Writing}

Writing is a complex task that demands cognitive effort and time. White and Arndt (1996) argue that "writing is far from being a simple 
matter of transcribing language into written symbols: it is a thinking process in its own right, it demands conscious intellectual effort which usually is sustained over a considerable period of time" (p. 3). Likewise, Hyland (2002) has highlighted that writing is essentially a problem-solving activity that implies different processes. From this viewpoint, writing is a skill that allows people to communicate and convey meaningful messages to interact with readers within a context.

Writing is more than putting words together onto a paper; it encompasses time, knowledge, addition of ideas, and information. Byrne (1998) states that writing is "a sequence of statements arranged in a particular order and linked together in certain ways" (p. 1). As the author affirms, writing involves encoding a message or thoughts that are translated into language and decoded through reading. As stated above, writing implies organization of sentences in a coherent way, giving sense to the text in order to capture the readers' interest.

English as a Second Language (ESL) students see writing as a complex process, even in their mother tongue. Nonetheless, it is a common situation that a learner's skills and strategies, used in reading and writing in the first language, are transferred to another language (Cummins, as cited in Shin \& Crandall, 2014). It is interesting to find that Shin and Crandall (2014) state that, when learners write in their own language and their English proficiency is enough, they can transfer those skills into their writing in English.

\section{Teaching writing to young learners}

According to Scott and Ytreberg (1990), the art of writing is not concerned with the here and now, which is where many young children exist for a lot of the time and practice. Calkins (1994) posits that writing activities and vast opportunities to write help to consolidate the learners' knowledge, allowing them to express their personalities and use a wider range of grammar structures and vocabulary because learners have more time to think and learn from models provided by their mentors or teachers. When students are exposed to extensive times of writing, they can edit and revise their own written piece independently.

In order to maximize learning conditions in the classroom, teachers must provide an environment where optimal writing development 
can take place. Scott and Ytreberg (1990) state that, in order to promote writing development, young learners need meaningful writing immersion or experience; interaction with examples of writing; positive expectation provided by the teacher; active participation in their own learning; approximation or value effort; use of writing forms; and response or feedback. Apart from these conditions to develop optimal writing, Shin and Crandall (2014) highlight that young learners need to write outside the classroom in order to communicate something for a real audience. Hence, children need the opportunity to engage in creative writing and write authentic texts for authentic purposes. Furthermore, Atwell (1987) points out that a teacher's role is to help students approach written language as "insiders" who have their own intentions (i.e., topics, purposes), and to use "insider" language to draft, edit, and ask for advice to choose or reject their word choices and ideas when writing. The author suggests that teachers should help learners to use the insider role, in which they have time to think and freely write based on their interest and at their own pace instead of complying with the teachers' writing expectations.

It is evident that the writing process becomes easier when students write about topics that are familiar to them and when they accomplish appealing tasks; therefore, it is advisable for teachers to articulate students' writing assignments with their interests, needs, and prior knowledge. A way to assign writing in language classrooms is to use the Form, Audience, Topic, and Purpose (FATP) system as suggested by Shin and Crandall (2014). They posit that every writing assignment should have a specific form or type of writing, audience or someone who reads it, a topic or something to communicate, and a purpose or reason to write.

\section{The process approach to writing}

Some authors suggest that professional writers usually plan, draft, revise, and confer with an editor in order to publish. They affirm that the best way for children to learn to write is to use the same processes as professional writers do because the PBA is a method of discovery through language (Calkins, 1994; Graves, 2003). In addition, Calkins (1994) remarks that this approach serves to explore what students al- 
ready know and how they feel about what they know using the language. Young learners employ the language to learn about the world, to evaluate what they learn, and to communicate. For that reason, Calkins (1994) agrees that teaching writing to young learners is to bring their lives on written words and to live a writerly life, so children need to be shown the whole art of writing and be encouraged to do likewise using their prior experiences.

Chavez, Matsumura, and Valdes (2004) claim that the process approach to writing instruction emphasizes a cycle of revision during which students draft, edit, revise, and redraft their work. From a process perspective, writing development involves four key processes: planning, transforming ideas into language, its orthographic representation, and rewriting text in order to improve it. The authors state that, in this approach, feedback from teachers or peers and the opportunity to revise written work based on this formative response or comment are essential to the students' development as writers, and the role of instruction in early learning of writing has become crucial. Furthermore, Raimes (1983) and Ferris (2002) point out that feedback helps learners to develop their metalinguistic awareness and that it is associated with writing improvement; thus, learners gradually develop the skills necessary to view their own work critically, revise it, and become better writers.

Shin and Crandall (2014) state that the process-based approach to writing helps young learners to express their ideas, construct meaning, and explore their linguistic resources. This approach takes young learners through a series of steps to structure and communicate their ideas, focusing on expression in the early stages, and only being concerned with accurate grammar or mechanics in the final stages. Moreover, Hedge (2005) asserts that, through a series of stages, the process approach helps learners to become more fluent and accurate writers.

\section{Writing as a process}

Lawrence (1996) defines writing as a thinking process, since the writer needs to know how to organize ideas and messages appropriately by changing, revising, and adding words or structures before moving forward; those thoughts are finally imprinted in written form. Moreover, 
Sapkota (2012) states that "not only the writing process can help to reconstruct thinking into the written form; it also supplies important clues for improving the coherence of the text" (p. 71).

White and Arndt (1996) suggest that the process of writing may be a more effective method of teaching writing, since it helps learners to focus on the process of creating text through various stages. Although not every learner uses all aspects of the writing process in every piece of writing, White and Arndt's (1996) model is presented to show the essential elements and to convey the nature of the process.

Figure 1. A model of the writing process figure

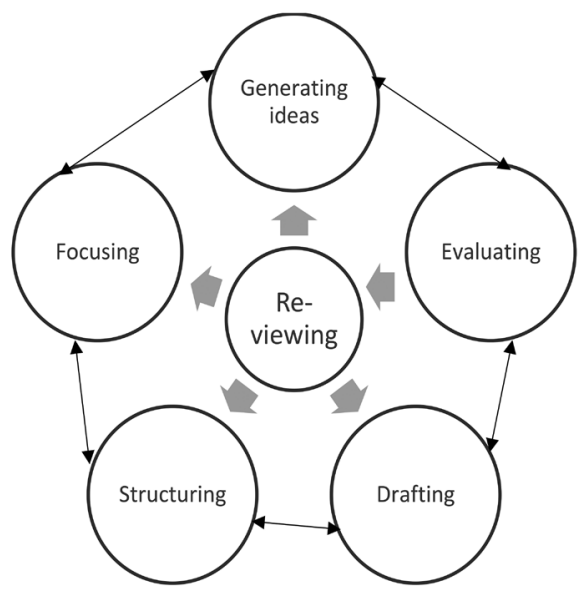

Source: White and Arndt (1996, p. 43).

Sapkota (2012) believes that generating ideas is a crucial stage of the writing process since it deals with organizing information and communicating meaning. For this reason, the author suggests that students follow certain activities in the initial stages when they are attempting to discover a topic and identify the purpose. According to White and Arndt (1996), the teacher's role at this stage is to help students to draw on previous experiences by recalling special events or talking with individual children about personal interests. Techniques such as bubbling, or mind webs, suggested by Sundem (2006), are employed to generate ideas in a central topic.

Focusing and structuring are techniques that include looking for main ideas and establishing the text's purpose. White and Arndt (1996) 
consider that the meaning of the text entails many processes of organizing and sorting out ideas in order to establish the meaning of the text. These authors concur that the writer starts with a general organizational scheme and that new ideas are generated throughout the writing process.

Drafting is one of the main stages in the writing process. White and Arndt (1996) and Sapkota (2012) agree that many of the activities described in earlier stages are categorized as "pre-writing." They also argue that the main concern of the writer in writing is how to organize an idea for their reader since the writer must think of how to capture their audience's attention and lead them through the text to the conclusion. At this stage, the focus is on getting ideas on paper and not worrying about spelling, grammar, or even word choice; fluency is the goal of this stage (Shin \& Crandall, 2014).

The evaluation stage is crucial to make sure that the language is clear, and reasoning well maintained (Sapkota, 2012). In general, White and Arndt (1996) assert that the assessment stage of the draft must consider the length of the text, organization, and the mechanics of writing. Peer review and conferencing are common techniques used to evaluate a writer's piece, focusing on the content, helping the writer to see what the audience likes and understands (White \& Arndt, 1996, Calkins, 1994; Sapkota, 2012).

Among the approaches to writing instruction, Harmer (2004) suggests a series of steps to carry out the writing process. First, planning what they want to communicate, which includes three aspects: purpose, audience, and content of the writing. Second, drafting as a simple, free writing version that focuses on meaning and getting ideas on paper to be polished during the following stage. The revising stage is the third stage, in which the writer makes changes as suggested by a peer or teacher after receiving formative feedback. Harmer (2004) mentions that, in the revising stage, it is important to modify the text checking for meaning, content or coherence. Finally, the last version is the result piece of work that may look considerably different since it has gone through an editing process. As stated above, this process is not linear, but rather recursive, as stated by Byrne (1998). Harmer (2004) developed a representation of writing as a process in the form of a wheel (Figure 2), which shows how the writer can take different directions throughout the process. 
Figure 2. The writing process wheel

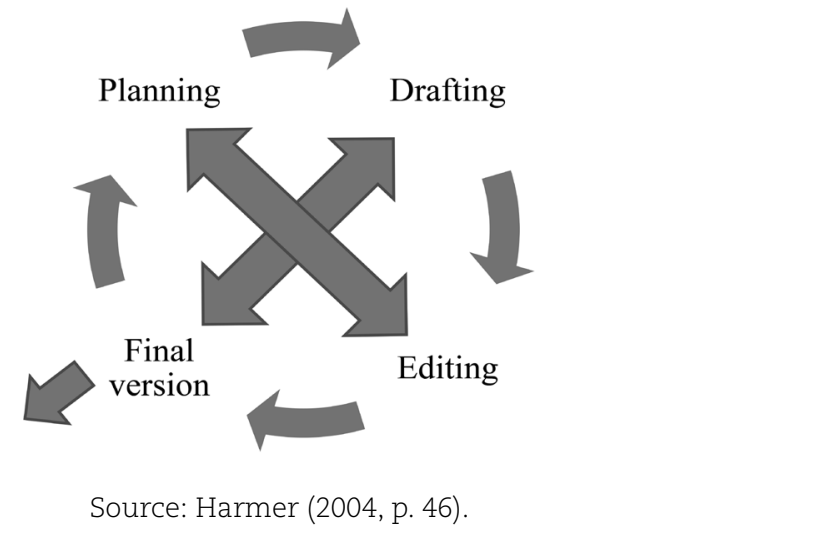
sumes that they should create "the right conditions for the generation of ideas, persuading the students of the usefulness of the activity and encouraging them to make as many efforts as possible for maximum benefit" (p. 330). Furthermore, Brown (2007) suggests that efficient writing needs to consider students' cultural background and provide opportunities for authentic writing by following the writing process, promoting interaction, applying effective feedback techniques, and instructing students on formal and rhetorical conventions of writing. Harmer (2007) states that writing involves a process of generating, formulating and refining one's ideas; therefore, writing practice in class should reflect the same process where attention and sufficient time are provided for revision and drafting while the teacher intervenes throughout the whole process, giving formative feedback.

\section{Strategies to develop the writing skill in young learners}

The process of writing involves cognitive, linguistic, affective, behavioral and physical components (Serravallo, 2017). Some authors believe that the use of writing strategies deals with how students understand their own writing processes, and how they adapt their processes to evolving demand (Harris, Graham, Manson, \& Friedlander, 2008; Oxford, 2001). Serravallo (2017) has suggested a series of strategies to foster students writing at different grade-level. There are various strategies to be used when writing; nonetheless, this study involved the use of three main ones: planning, monitoring, and evaluating. 
Planning involves focusing on purpose, audience, ideas, and strategies to be used, among others. It often takes place before writing, but some writers also plan their compositions even while they are writing. Planning writing is more efficiently done by small-group brainstorming some clue words and related topics for writing.

Serravallo (2017) asserts that monitoring involves controlling the writing process in general aspects of writing, such as content and organization, and in terms of specific aspects, such as grammar and mechanics. The author suggests that using checklists is pivotal at this stage to help young learners to guide their thinking and self-assess their own writing.

The author considers that evaluating takes place after writing the draft, and it consists of redrafting the text in terms of content, organization, and conventions. Serravallo (2017) highlights that this strategy is more efficient when it is done as peer assessment. Graves (2003) states that peer evaluation is a form of conferencing that helps students to value what they know when talking about their work with peers or the teacher, whose role is to be active listeners and help learners react to their writing. This author adds that sharing the draft with another peer helps the learners realize how their audience understands the written piece.

\section{Method}

The type of research adopted for this study was Action Research, which intends to improve an educational practice of EFL teaching (Kemmis \& McTaggart, 1988). This study encompasses the identification of a problem concerning the students' writing process and the implementation of an intervention to improve it. Thus, once the problem was identified, the questions were asked to gather information, data were analyzed and collected, and the actions were considered for the intervention.

\section{Participants}

The participants in the study included twelve students from a private bilingual school. This population was chosen under a convenience 
stratified sampling technique suggested by Creswell (2008). There were twenty-six students in the third grade. The researchers chose that class because learners shared the same academic context and had similar characteristics in terms of age and language proficiency level. After that, the third graders were divided into two subgroups: high and low English proficiency level, based on their class performance. Later, twelve students from the low level were tested in their communicative skills using a standardized assessment test (the Young Learners English Starters: YLE Test). The results showed that twelve students had a low performance in writing. Finally, the population chosen shared similar class characterization; there were six boys and six girls with ages ranging from 10 to 11 years old.

\section{Techniques for data collection}

\section{Diagnosis: before the process-based writing intervention}

Prior to starting the pedagogical intervention, the researchers administered two surveys to elementary-school students and teachers in order to identify the students' strengths and weaknesses in the language. Additionally, some non-participant class observations were carried out to learn about the students' actions, behaviors and attitudes towards the class, instructions, tasks, and the target language. Finally, the researchers conducted a documentary analysis to get to know the students' English learning background and institutional teaching/learning beliefs from different sources.

After that, the data were codified, categorized, and analyzed through coding technique suggested by Creswell (2008). Following this, the students took a pre-test, whose purpose was to identify their writing performance, considering the writing traits and writing process.

\section{Action stage: after the process-based writing intervention}

The teacher researcher applied different data collection instruments to track the students' progress and improvement in their writing skills. The participant's observations were carried out to gather data from a teaching perspective about the students' behaviours, attitudes, and changes after administering the strategies tasks and the PBA included in the workshop. Furthermore, the self-assessment 
checklists served to examine students' perceptions on writing performance considering the categories found in the diagnostic stage in terms of the use of writing traits and the writing process. The categories found were 1) reluctant attitude towards writing; 2) weaknesses in writing traits; 3) students' limited vocabulary; and 4) need of writ84 ing strategies.

The researchers used the lesson reports (artifacts) to determine the students' possible progress or setback after applying the strategies of intervention. On the other hand, the students' performance regarding the implementation of the writing traits and the strategies was analyzed. Moreover, the external observer was present in two different workshops, whose purpose was to have a different point of view of the students' progress. Likewise, a post-test was administered to know the level students achieved at the end of the implementation using the same structure as the pre-test.

To develop the project, the following research question was stated: To what extent can the PBA influence the writing skill of third graders at a bilingual school?

The specific research objectives were to determine the type of assistance that the stages of the PBA offer third-grade students in writing skills; to establish what happens concerning writing traits when EFL learners are exposed to the PBA to write; and to verify the students' levels of confidence when working under the PBA.

The researchers designed and implemented six workshops following established stages, named as: warm-up, presentation, guided and free practice, and self-assessment. These workshops promoted interaction patterns based on learner-centered pedagogy and collaborative work.

The participants of the study were part of an EFL Language Arts classes. The PBA was used for the writing intervention, so the learners were asked to carry out one writing task per week considering the writing process stages and employing strategies to plan, monitor and evaluate their writing. Graphic organizers were suggested to brainstorm and generate ideas before drafting. Moreover, to monitor their work, students used a checklist and discussed it with the teacher. Finally, the evaluation of the task was done through peer review and a self-assessment checklist. The topics for the workshops covered were chosen considering the students' age, likes, level, and context. 
The learners developed their tasks in five stages by following the Writing Process Model proposed by Harmer (2004) and White and Arndt (1996). The stages included pre-writing, drafting, revising, editing, and publishing. Each stage accounted for a writing strategy to be developed in the pre-writing (planning), while-writing (monitoring), and post-writing (evaluating) stages. During the first stage, prewriting, the students brainstormed ideas and wrote the outline of their draft by considering a written sample. In the while-writing stage, the students free-wrote their draft, which involved revising it with the assistance of the teacher and a checklist. Then, they continued with the post-writing stage, in which they proofread, received feedback from the peer, and edited their work.

The pedagogical implementation of the present study consisted of 6 eight-hour sessions and a mini-lesson (introductory session), as illustrated in Figure 3.

Figure 3. Classroom intervention through the PBA to writing

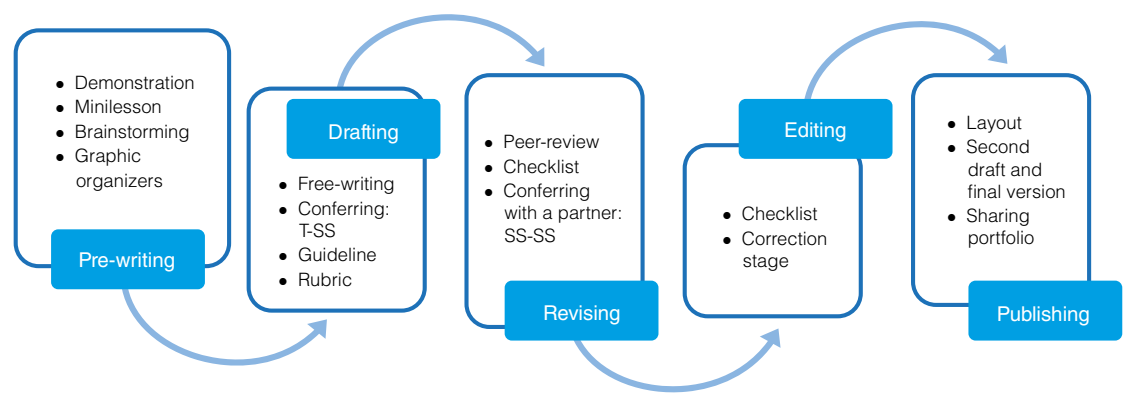

Source: Sánchez and López (2018).

Figure 3 displays the phases applied in the classroom intervention. Six workshops were divided into pre-writing, while-writing, and post-writing tasks. During pre-writing, new vocabulary was presented to the students. After that, there was a mini lesson, where grammatical structure and text features were taught by means of a teacher's demonstration. During the while- and post-writing activities, students generated ideas using two graphic organizers. After that, they wrote the texts and revised them by conferring with teacher and peers; finally, they edited their second draft by peer-reviewing and self-assessing, which was done through checklists. In all workshops, 
three writing strategies (i.e., brainstorming, conferring, and peer-review), were introduced to assist students to pre-write, revise and edit their work independently.

The workshops were designed based on students' preferences, needs, and they included the four stages of writing proposed by Calkins (1994), who suggests the incorporation of activities inside the language classroom to promote the development of students' independent writing and awareness of writing strategies through a mini-lesson, practice, conferring, and sharing with a real audience.

\section{Results}

\section{Difficulties found in the students' writing skills prior to the pro- cess-based intervention}

According to the results of the data analysis during the diagnostic stage, writing was the most challenging skill for the students. They showed an insufficient vocabulary repertoire, limitations of strategies, a lack of use of writing traits to carry out a written task, and a low level of confidence. In the students' questionnaire, they admitted that writing was one of the most difficult skills due to the absence of lexical resources and syntactic devices.

The following excerpt, which was taken from the students' questionnaire, shows how participants could reflect on their weaknesses in their language skills, particularly writing. They confirmed that their writing skill needed to be intervened:

P3: "To write in English is very difficult. I do not know many words and time."

P11: "Speaking is easy for me, but writing I do not like it much."

Accordingly, the pre-test revealed that students could not write well because they did not organize their ideas into coherent sentences or paragraphs, which made their compositions unclear. In addition 
to this, students made mistakes in terms of writing conventions like spelling, punctuation, use of grammatical devices, and capitalization.

The second excerpt, translated from the students' pre-test, illustrates their writing difficulties regarding meaning, vocabulary range and syntax to display organized and clear sentences to write a short story:

P1: "Jack has a dog and they are friends' pirate."

P7: "The boy finds a dream in a box."

The students' behavioral moves and the teachers' answers in the questionnaire confirmed that they were not as confident as they should be when writing something, as seen in the third excerpt, which was taken from the teacher's journal:

P3: "Their oral production is fluent, but they are not able to produce in written form what they think or say, no matter if they have done it many times."

P10: "The boy finds a dream in a box."

Although students had a positive attitude towards learning English, writing incorrectly made them feel discouraged and nervous about the results obtained in the tasks.

The third most remarkable category found in the data analysis was vocabulary limitations, which was clearly identified during the non-participant observations of the lessons while students were performing writing tasks. Moreover, most problems with vocabulary had to do with the wrong choice of words in writing tasks:

P1: "The boy dug the shovel in the ground."

The researchers found three relevant categories in the analysis: the breakdowns in content, mechanics, and organization. They mainly neglected the use of connectives to display a structured composition. Most of the students made mistakes in word form, word order, sentence structure, word choice, and wordiness: 
"I have a hard time to understand the students' hand-writing. They constantly misspell words or they frequently write them as they sound out. Besides, they mostly write ideas that make no sense."

The following figure displays the results before the implementation of the PBA in the EFL class.

Figure 4. Data triangulation in the diagnostic stage

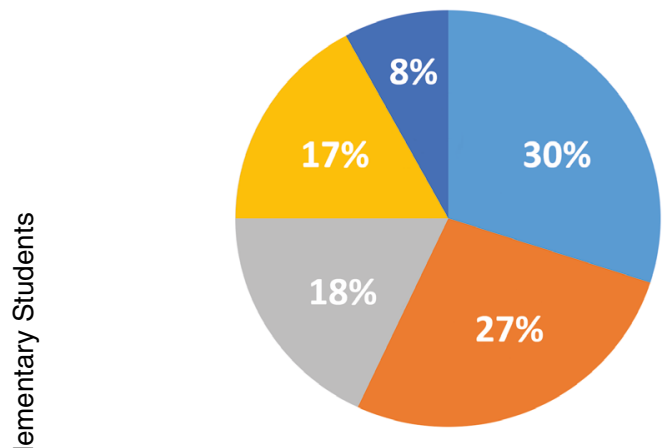

Low Writing Efficacy

Source: Sánchez and López (2018).

\section{Improved areas in writing skills after the process-based intervention}

According to the analysis of the data, the students' writing skill improved after the implementation stage. They wrote complete paragraphs with well-thought-out sentences connected with adequate linking words to develop coherent written pieces:

"I could observe progress on the students' writing skill, especially, on their grammatical foundations and writing conventions. It was surprising seeing these kids punctuating sentences accurately."

The implementation of the PBA influenced their writing, since they became independent and, therefore, their confidence improved. In addition to that, the students showed gradual progress in the use of complex constructions, such as correct grammatical structures, and appropriate use of punctuation, spelling, and tense, in general. 
The students used the writing process and different strategies to work on fluency, ideas, content, and voice as the use of planning, monitoring, and evaluating. Hence, the PBA functioned as a productive unit that contributed to ameliorate the students' difficulties in the structure of sentences and paragraphs. Figure 5 and 6 displayed the results the students obtained after submitting each written task.

Figure 5. Accomplishments in the PBA writing stages

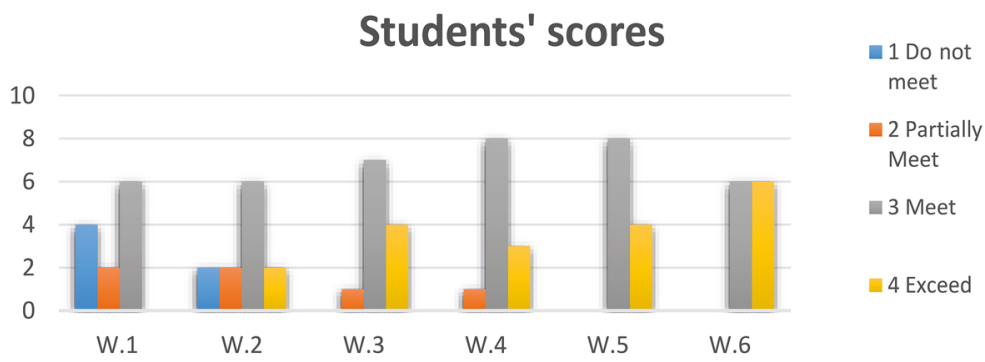

Source: Sánchez and López (2018).

Figure 6. Accomplishments in the PBA writing stages

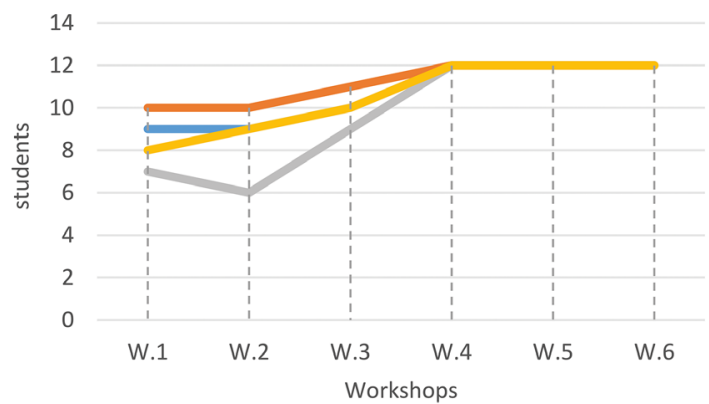

$\longrightarrow$ Pre-writing

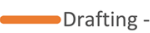

Conferring

Revision -Peer review

Editing Checklists

Source: Sánchez and López (2018).

The students' level of writing achievement was a relevant and evident aspect. All the features that were considered in the writing' quality (traits) showed progress. It is important to highlight that the revision and the edition of the drafts were the criteria with the highest improvement. The students noticed that writing was a process of steps from brainstorming an idea to writing a complete text-type: 
"I followed the writing process independently and I did well when I wrote confidently with little support from my teacher."

This excerpt exemplifies how the students reflect on the opportunities they had to learn about the writing process, which lowered their affective filter towards writing in L2.

Furthermore, based on the results of the rubrics, the students used the process and writing strategies to work on fluency, ideas, content, and voice, since they monitored, planned, and evaluated their compositions by means of graphic organizers, conferring, and checklists to arrange the main points of their paragraphs of their texts. Thus, the strategies applied in the workshops were effective since their final drafts reflected good content, organization, with well-organized paragraphs and ideas following a coherent pattern. Despite the mistakes in writing conventions in some of the students' drafts, their intended messages were conveyed effectively:

\footnotetext{
"The scores obtained in the artifacts were satisfactory. All the students met the standards; four students exceeded the standards, demonstrating high level of accomplishment during this writing task."
}

The young, third-grade learners were resourceful to include words to express their thoughts in a coherent and accurate way. These results confirmed the positive effect that the PBA had on the students' writing and life-long learning skills:

P5: "I did well in the workshops because I followed the writing process and I wrote confidently and independently without my teacher's help."

As for the strategies applied during the different stages, most of the students displayed automaticity during the prewriting and editing stages, since the writing strategies aided them to generate ideas and to understand the purpose of the tasks and the structure of the texts. Most of the students believed the PBA methodology promoted language and thus it helped them develop their writing skills. 


\section{Language Elicitation Measure: Writing a Narrative (Pre-Test and Post-Test Analysis of Results of Pre-Test}

Figure 7 displays the results found in the diagnostic stage in the pre-test that the students took before the intervention. It was about writing a short story using some images as a reference.

Figure 7. Results from the diagnostic stage in the pre-test

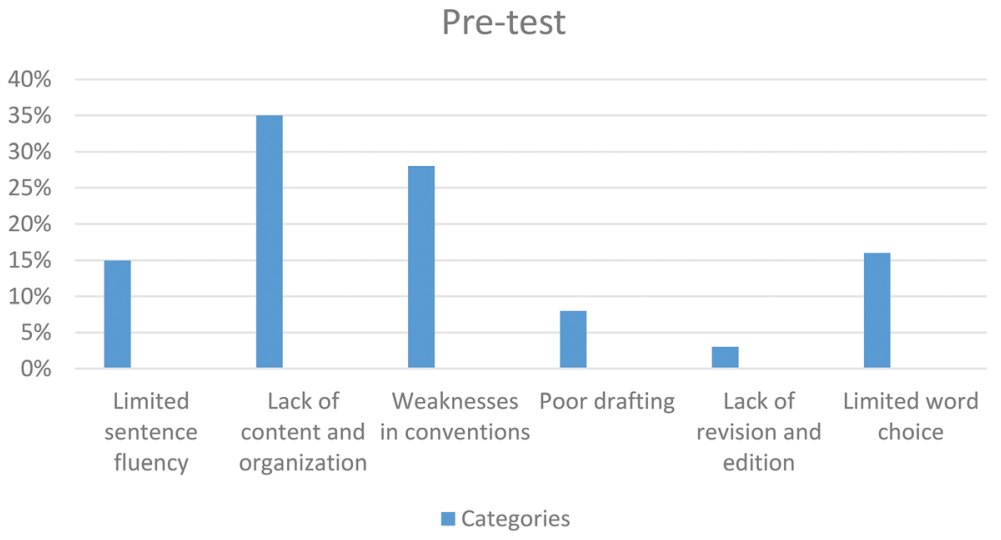

Source: Sánchez and López (2018).

During the diagnosis, students had hardly met the standard and displayed low writing performance. They showed incomplete sentences, deficiencies in the use of the period, capitalization, and comma, and misspelled words when writing their narrative. To illustrate this, $75 \%$ of the participants did not write pronouns correctly, 58\% misspelled high-frequency words and did not capitalize them, $66 \%$ omitted agreement between the verb and subject structure, and most of the students committed mistakes in word form, word order, sentence structure, word choice, and wordiness. The mistakes found were analyzed and categorized as follows: lack of meaning and organization (30\%); misspelling (28\%); lack of vocabulary and repetition (16\%); use of uncomsentences (15\%); limitations to convey meaning (8\%); and incorrect use of plural/singular (1\%). 


\section{Pre- and Post-Tests Analysis}

Figure 8. Pre-Test and Post-Test Comparison

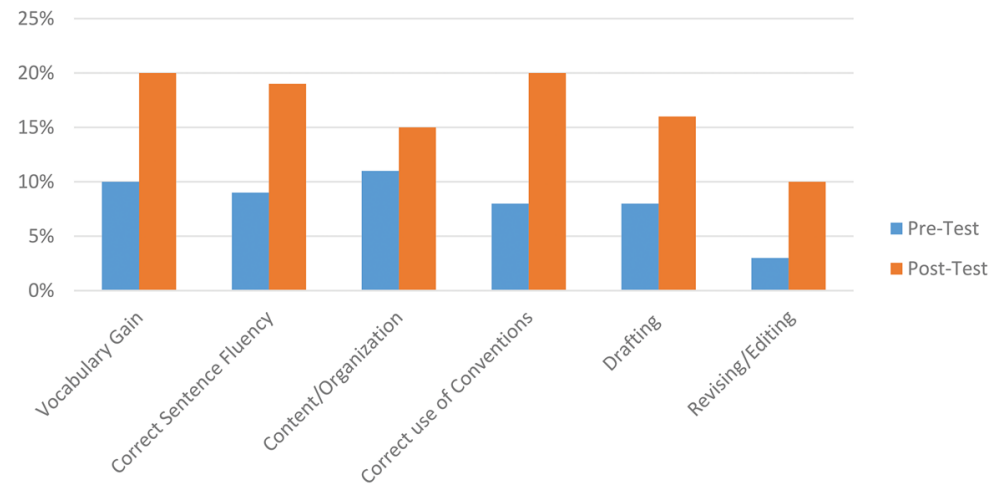

Source: Sánchez and López (2018).

In the post-test analysis, there was a significant progress in content, organization, and sentence fluency. Additionally, most of the students wrote coherent statements using appropriate connectors, and with a sequence of events and correct word order and sentence structure.

In general, most of the students achieved the purpose of writing following the parameters taught. There was a significant enhancement of the writing skills of the students when using the PBA, since all of them pre-wrote their story using their brainstorming strategy, proofread and edited their piece, and showed confidence when writing without asking for the teacher's assistance. Similarly, most students were resourceful in using strategies to find precise words to express their ideas, relying on their prior knowledge, visual aids, and language frames (vocabulary and grammar) to convey message.

Results showed that the amount of weaknesses in conventions, vocabulary range, content, organization, and limitations in confidence in the students' proficiency were reduced after implementing the PBA and writing strategies. Kroll (1990) remarks that the process approach "provides a way to think about writing in terms of what the writer does (planning, revising, and the like) instead of in terms of what the final product looks like (patterns of organization, spelling, and grammar)" 
(p. 96). The PBA lets students manage their own writing by giving them a chance to think as they write (Brown, 2001). Thus, students conveyed their messages to the readers or real audiences (their peers) in written form through the writing process of prewriting, drafting, revising, and editing.

The PBA and writing strategies empowered the students with the necessary tools to perform better in the tasks. In addition, this model was beneficial to students because it focused more on the various classroom activities. The students learned to use the strategies and gradually improved their performance, including conferring with their peers or teacher and peer revision, which promoted collaborative learning and formative feedback that aimed at improving the students' content, sentence fluency, word choice, and organization.

The students showed a high level of encouragement to write on their own, thanks to the collaboration of their peers to revise their work, the checklists, graphic organizers and conferences with the teacher to jot down their thoughts and achieve their goals effectively. The students took advantage of the presence of their peers to make writing a cooperative activity. This focus on working together gave constructive feedback and detailed work among the students because they focused on the writing process by reviewing, generating ideas, and evaluating their pieces of writing.

The PBA positively enhanced the students' quality of writing, displaying appropriate use of writing devices, such as sentence fluency, word choice, and mechanics. The results evidenced that students progressed significantly in their writing performance in terms of content, language forms, punctuation, and capitalization. Considering the results obtained from the analysis of the workshops, it was evident that students gained new vocabulary and reinforced their pre-existing vocabulary bank.

\section{Discussion}

\section{The PBA influences the development of writing skills and language instruction}

This flexible approach permits the integration of writing stages and strategies to keep a good balance between the production of a writing 
piece and classroom activities. Thus, students reinforce communicative language skills by means of explicit instruction, guided activities, pair-share, and collaborative learning. Consequently, the students need extensive opportunities to write on topics they are interested in to develop their writing skills.

Students need explicit and sequenced instruction to help them develop a learning progression, some formative feedback from different views that help them progress throughout next steps of the writing process. Powerful writing instruction produces visible and immediate results; the tasks that students produce become far more substantial and significant, revealing the young learners' ideas to real audiences. The PBA fosters writing as an interactive process that involves the writer, the text, and the reader so they can produce something for others to read. It is important to consider that young learners are in a beginner level; therefore, high proficiency cannot be the main goal. Consequently, it should not be expected that students produce whole compositions from the very beginning; they need, instead, to build the writing habit from early grades. Teachers need to provide students with motivating, straightforward tasks to persuade them to write and enjoy the process at the same time.

\section{The PBA and writing strategies foster self-efficacy in the writing process}

The PBA takes young learners through a series of steps to help them construct and communicate their ideas. Thus, the PBA is a language experience approach, since it leads children from guided writing to independent writing, helping them to become life-long learners and writers.

When applying the PBA model, teachers follow the "gradual release of responsibility" model of teaching, embedded in a self-efficacy approach to perform tasks with little guidance. Students can learn from demonstration accompanied by an explicit explanation, then from guided practice, in which the amount of scaffolding they receive lessens over time, and then from independent work, for which they receive feedback.

It is helpful to provide learners with simple checklists to guide their editing in preparing their final draft to develop self-efficacy be- 
cause this is how students can reflect upon their writing process and learning. The checklist must be adapted to reflect different levels of English proficiency and writing experience. It is necessary to continue implementing writing strategies such as brainstorming and peer review, thus students enhance not only their writing skill, but also lifelong learning competences.

\section{The PBA fosters positive attitudes towards writing}

Positive attitudes towards writing are evidence of the good effect that the PBA has on the writing skill. Writing techniques such as brainstorming, conferring, and peer-revision foster, improve and increase motivation towards writing and language learning, inspiring students to learn and practice L2, therefore teachers are recommended to involve the PBA and writing strategies in pair-share activities among peers since they encourage students to write and share their pieces of writing to real audiences. This output gives value to the students' purpose of writing. Consequently, writing activities should be meaningful, but also provide controlled and guided practice to support students in their writing development and language structure, vocabulary, spelling, and writing mechanics.

\section{The PBA promotes quality of writing and good writing performance}

Grammar and linguistic forms also improve when using the PBA in English class. Furthermore, this process helps with the acquisition of language structures and vocabulary. It is advisable to implement the PBA and writing strategies to assist students to increase and improve their grammar, and linguistic form, content, and organization. These characteristics should be developed from early grade levels, so students produce ideas, organize them efficiently, and elaborate the text to establish clear fluency and coherence. Since writing is an act of communication, it is necessary that students learn how to do it efficiently.

\section{The effect of the PBA and writing strategies on learners' lexis}

Constant written tasks lead students to increase and improve vocabulary recalling and retention, also giving them more confidence 
to take the risk when using new vocabulary words in real contexts. This language form cannot be taught in isolation, since learners need direct, targeted vocabulary input taken from authentic sources to produce coherent written output. The vocabulary expansion can be approached through reading passages, videos, discussions, and visuals inputs before asking learners to produce their drafts addressing a specific topic.

\section{Conclusions}

The participants in this study improved their writing procedures and the strategies they employed when writing in English. The actions they implemented to plan, draft, revise and edit focused almost exclusively on conveying the message and gaining certain accuracy of some lexical items. This indicates that the young English learners perceived the writing process as a way to transmit linguistic content and the application of L2 skills.

Because the PBA to writing might be one of the keys to helping students bridge the gap between writing as a classroom task and writing as a functional L2 communication skill, the ESL classroom should increase opportunities for writing when producing in the L2. Children under proper scaffolding, support, and formative feedback, might then eventually be able to develop better writing skills and employ the adequate writing strategies that fit their needs.

Sample size was a limitation on this research. There were only twelve students who worked and were assessed under the PBA. Hence, this small size of population might have been insufficient to demonstrate that the implementation could have a positive effect on the writing process of a large sample-size. For this reason, for future research projects it will be advisable to select a broader sample population in order to have more data to be analyzed. The PBA to writing should be introduced gradually into the language classroom by considering simple skills, such as planning writing first. Then, once learners have gained confidence in going through the stages of writing, such as drafting, revising, and editing, more challenging written tasks can be introduced. 
Ultimately, this study sheds light on how process-based activities can assist ESL students in the process of becoming better writers when such interventions are carefully aligned with a realistic knowledge of the writing process and strategies of students and appreciation of their writing abilities.

\section{References}

Atwell, N. (1987). In the middle: Writing, reading, and learning with adolescents. Portsmouth, NH: Heinemann.

Brown, H. D. (2007). Principles of language learning and teaching. White Plains, NY: Pearson Longman.

Byrne, D. (1998). Teaching writing skills. Harlow, UK: Longman.

Calkins, L. M. (1994). The art of teaching writing. Portsmouth, NH: Irwin Publishing.

Chávez, G., Matsumura, L., \& Valdés, R. (2004). Investigating the process approach to writing instruction in urban middle schools. Journal of Adolescent \& Adult Literacy, 47(6), 462-477. Retrieved from https:// www.jstor.org/stable/40018722

Creswell, J. W. (2008). Educational research: Planning, conducting, and evaluating quantitative and qualitative research. Upper Saddle River, NJ: Prentice Hall.

Elbow, P. (1973). Writing without teachers. New York, NY: Oxford University Press.

Ferris, D. (2002). Teaching students to self-edit. In J. Richards, \& W. Renandya (Eds.), Methodology in language teaching: An anthology of current practice (pp. 328-334). Cambridge, UK: Cambridge University Press.

Fountas, I. C., \& Pinnell, G. S. (2001). Guiding readers and writers: Teaching comprehension, genre, and content literacy. Portsmouth, NH: Heinemann.

Gass, S., \& Selinker, L. (2008). Second language acquisition: An introductory course. New York, NY: Routledge.

Graves, D. (2003). Inside writing: How to teach the details of craft. Portsmouth, NH: Heinemann.

Harmer, J. (2004). How to teach writing. Harlow, UK: Pearson Longman. 
Harmer, J. (2007). The practice of English language teaching. Edinburg Gate, UK: Pearson Longman.

Harris, K., Graham, S., Mason, L., \& Friedlander, B. (2008). Powerful writing strategies for all students. Baltimore, MD: Paul H. Brookes Publishing Co.

Hedge, T. (2005). Writing. Oxford, UK: Oxford University Press.

Hyland, K. (2002). Teaching and researching writing. London, UK: Pearson Longman.

Kemmis, S., \& McTaggart, R. (1988). The action research reader. Geelong, Australia: Deakin University Press.

Kroll, B. (1990). Second language writing (Cambridge applied linguistics): Research insights for the classroom. Cambridge, UK: Cambridge University Press.

Oxford, R. (2001). Language learning strategies. In R. Carter, \& D. Nunan (Eds.), The Cambridge guide to teaching English to speakers of other languages (166-172). Cambridge, UK: Cambridge University Press.

Raimes, A. (1983). Techniques in teaching writing. New York, NY: Oxford University Press.

Saptoka, A. (2012). Developing students' writing skill through peer and teacher correction: An action research. Journal of NELTA, 17(1-2), 70-82. DOI: http://dx.doi.org/10.3126/nelta.v17i1-2.8094

Scott, W., \& Ytreberg, L. (1990). Teaching English to children. London, UK: Longman.

Sundem, G. (2006). Improving students writing skills. Huntington, CA: Shell Education.

Serravallo, J. (2017). The writing strategies book: Your everything guide to developing skilled writers. Portsmouth, NH: Heinemann.

Shin, J. K., \& Crandall, J. A. (2014). Teaching young learners English: From theory to practice. Boston, MA: National Geographic Learning.

White, R., \& Arndt, V. (1996). Process writing. London, UK: Pearson, Longman. 